\title{
4 \\ Spaces and places of governance and resistance
}

Amaal: I came to live in Barking and Dagenham twenty-five years ago and at that time ... very few black and Asian and ethnic minority communities ... and within a short space of I would say maybe five years or so the borough has changed dramatically and quite a lot of migrants arrived and that created a little bit more tension within the wider community and evidently you can see the changes, you know, people say 'Oh, nothing's changed', but you can actually see the presence of people, family influx are coming in, but what we know as an organisation is that these people arriving in Barking and Dagenham, not necessarily come from abroad, you know, it is quite a mix. Some of them came [to] inner city London and moved to Westminster borough and Islington and those areas, where the cost of living is quite high and the rent has gone up and people cannot afford in private to rent. So those are families that are being really pushed from inner cities to outer London that we know and some really as far as, they come from within East London, Tower Hamlets and people who come to Barking and Dagenham from Tower Hamlets now also and other boroughs in Waltham Forest where there is cheaper houses here and affordable to live in Barking and Dagenham. But not everybody sees that, we know, because we have some of these families accessing our services, but people think, you know, that these people are new arrivals and they're just sort of off the plane and just arrived in Barking and Dagenham, but there's quite a big difference and the majority of them, they are resident in the UK, but just came to Barking and Dagenham because of the cheaper and affordable housing.

(Barking and Dagenham Activist Interview, conducted by Yasmin)

The philosopher and social theorist Michel Foucault once said, "We are in an epoch of simultaneity: we are in an epoch of juxtaposition, 
the epoch of the near and far, of the side-by-side, of the dispersed' (1986: 22). He might well have been in a conversation with Amaal, a community worker in Barking and Dagenham, quoted above. Amaal's observations of her local area - how it has changed over the years, how there are more complex histories and lives beneath appearances - tells us something important about space and place in modern urban life. As places heave and pulsate with social changes and the proximities of all sorts of differences, we can also cling to place to provide some stable and idealised sense of belonging, community and home (Bammer, 1992; Probyn, 1996).

In this chapter we explore some of these themes and the role of spaces and places in the implementation and reception of, and resistance to, immigration policing campaigns. First, the chapter examines the spaces where the campaigns have intervened, from people's homes, to the street, to cyber space. Building on the argument that such interventions are closely tied to the increasingly domestic nature of border practices as part of a highly visible performance politics (see Chapters 2 and 3), this chapter focuses on the intended and unintended consequences of campaigns. These include acts of resistance, increased fear and feelings of exclusion.

For us the spaces where these anti-immigration interventions (and reactions to them) unfold are not mere backdrops to action. Because space is alive, dynamic and relational, it is always affecting and being affected by what happens in it (Massey, 1994; Lefebvre, 1991). As we argued in Chapter 2, immigration campaigns seek to intervene in political space (Lefebvre, 1991: 33). Here, we look more closely at how campaigns such as Operation Vaken, and resistance to them, feed into the production of particular spaces, for example the intensification of fear associated with the street and with the waiting room at the local Home Office reception centre. It is also the case that the history and meanings of particular places have been mobilised to resist these campaigns.

Drawing on interviews and focus groups carried out in our six UK case study areas (Glasgow, Bradford, East London, West London, Birmingham/Coventry and Cardiff), we highlight how local and national contexts come to matter in how immigration policing campaigns are experienced and interpreted. Here local issues, such as histories of migration and resistance, and national contexts, such as debates about devolution and the 2014 Scottish Independence referendum, impact on reactions to anti-immigration campaigns. Whereas in Ealing and Hounslow (West London), for example, the Go Home van's appearance played into divisive discourses of respectability among established migrants and British citizens (discussed in Chapter 
5), in Glasgow opposition to Operation Vaken fed into debates about Scottish Independence.

This chapter argues for the importance of considering the following when examining the impact of anti-immigration campaigns across the UK:

1 the specific characteristics of sites of intervention and resistance

2 how local contexts shape reaction and resistance and, conversely,

3 how anti-immigration campaigns feed into the production of spaces and places.

\section{Place matters: vans in the street, raids on the home}

The 'hostile environment' of Operation Vaken and associated initiatives was a multilayered campaign intruding into different kinds of spaces: from the virtual environment to the street, to the intimate spaces of people's homes. These spaces became interlinked as social media were used to circulate information about Vaken's activities in the street and to organise counter-actions (see Living Research Five) - and, as we shall discuss below, the realms of the street and the digital also became interlinked through resistance to these campaigns.

The Go Home vans were possibly the most public aspect of the government's increasingly hard line on immigration, intervening directly in the streets of several ethnically diverse London neighbourhoods (Hounslow, Barking and Dagenham, Ealing, Barnet, Brent and Redbridge). Promising a sense of security that 'something is being done' about an invisible bogeyman (while reinforcing a feeling that the bogeyman lurks among them/us), the impact of the Go Home van travelled beyond the localities through which the vans drove via extensive media coverage. When considering the intervention that the vans made in London, it is not only the wider context of the city as 'global' (Sassen, 1991), or 'superdiverse' (Vertovec, 2007) that matters but how this is lived within the specific contexts of the neighbourhoods where the vans and their message were experienced.

We conducted research in three of the boroughs where the van was piloted: Ealing, Hounslow and Barking and Dagenham. Activists in these areas reported how the vans exacerbated existing tensions in the community. For example, in Barking where feelings on immigration run high, an activist explained:

Amaal: The Go Home vans affected the area, because Barking and Dagenham was one of the areas that was targeted, in terms of the 
migrant community, I mean, you know, with all the incidents that happened ... 'Go home', that sentence, really that resentment people feel and that is if someone's going to be racist, that is the sentence people are really angry about and feel quite violated if someone says to them 'go home' and for the Government to come up with that ... that is a green light for others to use [it] as well. So that was one of the things that really caused tension in Barking and Dagenham for both communities at that time.

(Barking and Dagenham Activist Interview, conducted by Yasmin)

The specific context of Barking and Dagenham is important here. It is a London borough that has seen a massive loss of jobs, most notably at the Ford factory, which went from employing forty thousand people at its peak in the 1950s to four thousand in 2009 (Hudson, 2009 cited in Simmons, 2014). It has a pressurised housing market, fuelled by the reduction in social rented housing following Thatcher's 1980s institution of the right to buy council properties without the power for local authorities to replace their housing stock (Asthana, 2010). The area has seen significant demographic change in terms of the ethnicity of the residents - the White British population decreased from 81 per cent in 2001 to 49 per cent in 2011 (London Borough of Barking and Dagenham, n.d.). In the early 2000s Barking and Dagenham was targeted by the far right, culminating in the British National Party becoming the official opposition to the Labour council in the elections of 2006, although it lost these seats in 2010. Jones argues that after the 2006 election: 'The borough came to symbolize, for both national press and policy practitioners across the country, the problem of far right mobilisation among the white working class' (2013: 43).

This local context matters when considering the impact of the Go Home van. To return to the interview extract, the van circulating in this locality upset those who are imagined as part of the 'migrant community', by echoing the language of the far right. It exacerbated a division between those who might say 'go home' and those who might be on the receiving end of these comments. The van thus feeds into the formation of and antagonism between what Amaal terms 'the two communities'. As the next chapter will explore in more detail, this division between two imagined communities does not correspond neatly to lines of 'race'. As another activist told us:

Ceebla: We've had political leaders, councillors defect in Barking and Dagenham to UKIP, who are from a minority ethnic 
background and it's incredible, it is absolutely incredible and on the basis that there are too many Eastern Europeans, it's just, it's so concerning that people are buying into this.

(Barking and Dagenham Activist Interview, conducted by Yasmin)

Interestingly, within this context the van did little to reassure those who held anti-immigration opinions. Participants in a focus group of white British women supporters of the UK Independence Party (UKIP), who describe themselves as being 'in the indigenous minority', dismissed the van as a waste of money:

Annie: It just shows you how stupid this government is.

Chris: It is.

Annie: To think that any illegal person is going to read that and go home ... not in a million years.

(Barking Focus Group, conducted by Yasmin)

So, for these women in this local context, the Go Home van also symbolises an out-of-touch government engaged in local theatrics that is not responding to what they feel is the real issue, for them, 'controlling the borders' (see also Chapters 2 and 3).

Meanwhile, on the other side of London, in Ealing and Hounslow, a focus group discussion with women of South Asian, African and Caribbean origin revealed a slippage between the understanding of the Go Home van's campaign (which four women in the group had seen) and vans that had been seen taking part in immigration raids:

Rita: It's so racist, I can say in my words, it's like we are Asian, we are from other country like Nigeria, Pakistan, India, so why is it only for us? It's coming in my mind straight away, it's showing so much racism.

Sukhwant: Why do you think it's directed at Asian and African communities? Is there something on this that suggests to you?

Rita: Because they grab the people, if you are walking in the street like me and other white people, they grab the Asian first, they don't ask any questions to white people ... they grab the people who have a dark complexion.

(Ealing and Hounslow Focus Group, conducted by Sukhwant)

The van is interpreted as 'racist' by this group because of its associations with immigration enforcement vans that 'grab' people rather 
than because of the messages displayed on the van. This slippage shows how anti-immigration interventions are not interpreted in a vacuum but rather interact with each other. In this local context, where raids are visible and frequent, vans mean raids.

The issue of raids loomed large in the two focus groups conducted in Ealing and Hounslow. Raids and checks in the street had major impacts on how public spaces were experienced. Even those who had leave to remain in the UK expressed anxiety about being stopped at transport hubs. Rita also described how she panicked when she saw UK Border Agency (UKBA) ${ }^{1}$ officers and dogs at the exit barriers of a London railway station (see Chapter 2). She became so nervous that she turned away from the exit barriers and jumped on a train. In this panic, she boarded the wrong train and when she eventually reached home she stayed indoors for some time because of a fear that her leave to remain might be revoked.

In the West London focus groups immigration enforcement was also seen as a threat to even the most intimate of spaces. Women in the Ealing and Hounslow focus groups talked about the frightening experience of having their homes raided. Others had seen them happening nearby, as Iram recounted:

Iram: I also saw immigration raids in Southall. Where I was living an illegal young man was also living. He was sleeping and they came and took him from his home. These raids are happening quite a lot in Southall and I was scared.

(Ealing and Hounslow Focus Group, conducted by Sukhwant, translation)

It was not only UKBA which was making incursions into the focus group participants' homes. Anjum, also in Ealing and Hounslow, remembered how her child was frightened by the landlord's constant intrusions:

Anjum: $[\mathrm{He}]$ used to knock the room twice a day and used to say we want copies of the passport and we want to know how long your sister is going to stay ... my little son was so much scared that he still doesn't meet that man [and] he has a problem in that house, he doesn't go downstairs when that 'uncle' is there.

(Ealing and Hounslow Focus Group, conducted by Sukhwant)

${ }^{1}$ UK Border Agency was the part of the Home Office responsible for border control between 2008 and April 2013, when it was split into UK Visas and Immigration, and Immigration and Enforcement agencies. 
These stories from Ealing and Hounslow evoke something of the cumulative effect of the layering up of anti-immigration interventions in multiple places at different scales - the home, the street - and the experience that no place is safe. Several participants wept as they considered the implications of this hostile environment for themselves and for people they know. From witnessing night-time raids in shared houses to seeing people on the street being carted off, they talked about the visceral impact of immigration policy on their lives and their new or increasing sense of precariousness.

The public and policy image of Ealing and Hounslow is rather different to Barking and Dagenham. Whereas Barking and Dagenham has become shorthand for community tensions and far-right success, Ealing incorporates Southall, an area that was used as a good example of community cohesion by the government in the past (Cantle, 2001). More widely, Ealing and Hounslow are home to a number of longstanding civil society organisations for which highlighting and opposing the racist dimension of immigration policy has been a key focus for decades. There is a large South Asian population in both of these boroughs. ${ }^{2}$ However, as described in the next chapter, heightened government and media attention to immigration has been divisive, including within the South Asian populations of these boroughs (see also Living Research One). Rita reflected on her experience of negative reactions during a protest against immigration enforcement:

Rita: SBS [Southall Black Sisters] took action against that van and I was with them, we were doing the campaign outside the Himalaya Palace and I was shocked, my Asian community they hate us. They were saying so many people, they are fighting, arguing with me now, and other people, they are saying 'why are you supporting them? They have to go home.' And I was shocked, my community hate me so what can I expect from British people? Of course they are going to be racist with me, they are going to hate me. If my community people they hate me, so who is going to

\footnotetext{
${ }^{2}$ The 2011 Census figures for Ealing put the biggest ethnic group as White English/Welsh/Scottish/Northern Ireland/British (30.4\%), with the next biggest single category as White Other (15.4\%) followed by Asian/ Asian British: Indian (14.3\%). For Hounslow, the 2011 Census shows that $37.9 \%$ of the population identify as White English/Welsh/Scottish/ Northern Ireland/British, with the next largest group who identify as Asian/Asian British: Indian (19\%), followed by $11.5 \%$ who identify as White Other. Source: Office for National Statistics, Neighbourhood Statistics table 'Ethnic Group (KS201EW): London'.
} 
accept us? So of course it's impacting my community, they have split us. My Asian community hate Asian people, it was so sad.

(Ealing and Hounslow Focus Group, conducted by Sukhwant)

In this case the lines drawn are not between resident and migrant but between 'good (established) migrant' and 'bad (new) migrant' (how this becomes discussed through the language of who is 'deserving' and 'undeserving' will be further explored in Chapter 5). In both East and West London the vans fuelled anti-migrant sentiments and divisions but, because of different histories of migration, this was interpreted and experienced differently. The imagined figure of the migrant 'other' is different in the two contexts. This depends on who the newcomers are in each community - the figure of the 'unrespectable' South Asian in West London, and the Eastern European in Barking and Dagenham, for instance.

But this government messaging did not circulate only on the streets of London. While the Go Home van element of Operation Vaken was implemented only in London, 26 per cent of Ipsos MORI's survey sample (see Appendix) was aware of it, making it the most visible aspect of the communications campaigns we asked about nationally. The Go Home van was covered extensively in the UK press, thus circulating far beyond the neighbourhoods through which it was driven. This led to some confusion among our respondents about the exact places of intervention (see below).

In addition, the official Home Office Twitter account began to share photographs of immigration officers apprehending people, leading them in handcuffs into the back of enforcement vans, with text such as \#immigrationoffender and \#nohidingplace. After substantial criticism (see Living Research Five), the Home Office quickly moved to a softer, less aggressive Twitter voice, focusing on missing persons and violence against women. But this short-lived social media strategy enabled the virtual circulation of these highly visible localised raids and therefore their use as anti-immigration propaganda. The tactic of making raids visible also included locally targeted actions such as taking journalists from local papers along to immigration raids on weddings, workplaces and homes (see Chapter 3).

At the same time, a more private poster campaign was taking place. The Brand Street (Glasgow) and Hounslow (London) Immigration Enforcement reporting offices were saturated with posters and stickers on the walls, chairs and floor, asking 'Is life here hard? Going home is simple,' accompanied by images of destitute people. There were also mobiles of planes hung from the ceiling. This campaign was much less 
public than the street-level interventions in London and was targeted at those already in a vulnerable position within the immigration system.

The adverse effects of displaying these posters in a place that is already feared by those who use it were described in focus groups in Ealing and Hounslow. When asked by Sukhwant about who in the group had seen the van, Angela's response was directly related to the reporting office poster campaign:

Angela:Yes not only on the bus, it was also in Home Office because I used to go in there, to sign on.

Sukhwant: The reception centres?

Angela: Yeah ... So when I went there, and saw it, oh - I just can't describe how I felt because I thought they put it here because they want to scare every single person. And it wasn't very good.

(Ealing and Hounslow Focus Group, conducted by Sukhwant)

As we also heard in Chapter 3, the posters in the reception centre add to fear within an already intimidating situation.

In Glasgow, where the Home Office posters were displayed without the van campaign, some of the focus group of asylum seekers and refugees had seen them in person but another person in the group refused to believe that this had happened in Glasgow - 'that was in London, not here' said one of the participants. In exploring why 'not here', the national context of Scotland becomes important.

\section{National matters: telling Immigration Enforcement to 'Go Home'}

We now zoom out from these smaller places and localities to consider how anti-immigration campaigns intervened in national contexts in the different countries of the UK, focusing particularly on Scotland and Wales where anti-immigration campaigns were used to draw distinctions between the countries in the UK.

The timing in Scotland was particularly significant, as the campaign unfolded in the run up to the 2014 Scottish Independence referendum. The Home Office reporting centre posters in Glasgow in particular and the campaign in general became reference points in the referendum campaign. The reaction to the campaign in Scotland was very negative. Key to the counter-campaign in Scotland was the argument that the posters were an intolerant Westminster imposition on (a more welcoming) Scotland. The Herald newspaper published an editorial that argued: 'The Scottish Parliament should make clear 


\section{Go home?}

that this kind of behaviour is not acceptable in Scotland. Perhaps it's time to tell the UKBA to "Go home" , (Herald View, 2013). This is just one example of how the campaign was used to distinguish between a punitive British state and a possible alternative Scottish approach, one that combines pro-immigration policies and civic nationalism. This also perhaps accounts for why one focus group participant from Glasgow refused to believe that the posters were displayed in Scotland ('that was London, not here').

The Scottish National Party (SNP) argued that UK policy on asylum and immigration was not in keeping with Scottish attitudes or the proposals for immigration and asylum in Scotland's Future (the White Paper on independence) that also included the proposal to close Dungavel Immigration Detention Centre. The White Paper explicitly references the 'Go Home' campaign to highlight these disparities:

It is [also] difficult to conceive of a Scottish government that would ever adopt the crude 'go home' approach tried by the current Westminster Government.

(The Scottish Government, 2013: 255-6)

Thus an inhospitable UK is held up against a welcoming Scotland and a promise of a fairer society to come. This position was echoed in a debate held in the Scottish Parliament in December 2013 on the poster campaign. All speakers of all political parties condemned the campaign but all SNP speakers used opposition to the campaign to stress the need for Scottish independence.

In a focus group carried out with refugees and asylum seekers in Glasgow we found strident pro-independence views. However, this seemed not to rely on feelings of belonging to Scotland as such, but rather on the specific policies on migration and asylum set out in the White Paper and on the idea of the Scottish state as generally more sympathetic than the Westminster government:

Sirvan: There is not any guarantee for new Scotland, or independent Scotland, that make life easy for refugees or asylum seekers, but still we believe that would be better because there is a campaign to support asylum or refugees. So the number of the population of Scotland is quite small, so it's quite easy to fight with the Parliament, you know Edinburgh Parliament, Scottish Parliament instead of UK.

Theresa: Because all the rules you are using here in Scotland ... the Home Office, their rules, they are from England.

(Glasgow focus group, conducted by Emma) 
In this focus group discussion, once again the Home Office is associated with the UK state (and equated with English dominance) rather than the Scottish government, which is characterised here as easier to access. Within this narrative of a more welcoming Scotland, we also found Glasgow to have a particular resonance (explored further below).

Although this was less pronounced in Wales, there was discussion in the focus groups about how immigration enforcement campaigns were largely Home Office, and therefore English, initiatives. In one of the activist interviews, Alex reflected on the situation of refugees and asylum seekers in Wales:

Alex: Compared to the rest of the UK, the situation in Wales is not as good as it is in Scotland, but it's better than the situation in England.

(Cardiff Activist Interview, conducted by Roiyah)

Debates on immigration in Wales have not had the same vehemence as in England, perhaps because of different and earlier patterns of immigration centred on the port city of Cardiff and dating back to the late nineteenth century (see Harries, 2015).

However, unlike Glasgow, in Cardiff devolution was not extensively discussed. The mood among immigration activists towards devolution was less positive than in the Glasgow research, and more sceptical opinions were voiced. One activist commented:

Crystal: Wales Government has no power [over immigration] but where they have the powers what did they do? Education, health, housing, community cohesion, what do they do? What has come out of it? What has come out of it? I don't know. I'm asking, what has come out of it?

(Cardiff Activist Interview, conducted by Roiyah)

There were significant differences between how the campaign fed in, or not, to debates about devolution in these two countries. In Scotland, the presence of the posters within Scotland itself, and in the local context of Glasgow as the country's most ethnically diverse city, during a time of fervent debate about Scotland's place in the United Kingdom made the posters highly symbolic of an unsympathetic state intruding on Scottish soil. Although Cardiff is also unusually ethnically diverse within Wales, here the campaign was not physically present but experienced via social media and the news. Unlike in Scotland, debate on devolution was not particularly heightened and 
so the campaign did not feed into discussions of nationhood in the same way.

\section{History matters: reaction and resistance}

Within these national debates, other more local forms of belonging are drawn upon in terms of resistance and mobilisation against antiimmigration campaigns. This was particularly noticeable in Cardiff and Glasgow, multicultural hubs in countries that are otherwise more ethnically homogenous than is England. In the Cardiff interviews and focus groups, the overwhelming majority of participants perceived Cardiff as different from other places in being more welcoming, friendlier and safer. The general street level conviviality, and the urban 'multicultured' areas, places and streets in which to socialise, worship and 'hang out' were noted as contributing factors. In this extract from a Cardiff focus group, Omar argues that anti-immigration campaigns do not have much impact on Cardiff:

Omar: I personally would think that Cardiff was a community itself. That would more or less bring them, bring the community together closer. And speaking from my experience because of the diversity and the way it's changed going ten years back. You work with Polish people, Turkish people, Moroccans and you work with the guy from the valleys, pure Welsh boy and you got someone from Ireland, you know Scottish, and they're all there. So who's going to say he's not from here? Who's going to say who should go, the Scottish guy, or the Moroccan, or should we all pick on the Irish guy or me, the black man?

(Cardiff focus group, conducted by Roiyah)

Omar's feeling is that because of the diversity in Cardiff, picking off specific groups as 'others', not entitled to belong, would not work. As well as this long-standing history of migration and multiculture, the twin factors of an increase in numbers of those seeking asylum in Cardiff since 2001 (since the policy of dispersal was introduced which moved thousands of asylum seekers to cities around the UK, in an attempt to ease pressure on services in London and south-east England) and the erosion of asylum seekers' rights have given rise to a wave of refugee-related activism in the city (Payson, 2015). The well-established anti-racist presence in Cardiff was another contributing factor. In the following exchange with Roiyah, Crystal, an activist 
in Cardiff, considers whether the van campaign would have been possible there:

Crystal: No, they couldn't even bring in to Cardiff anyway.

Roiyah: What, do you think it wouldn't have worked if they had the vans going up and down?

Crystal: It won't work. We are so barbaric in Wales it cannot work.

(Cardiff Activist Interview 2, conducted by Roiyah)

Here 'barbaric' refers to the stridency of local activism.

Like Cardiff, Glasgow has responded to the dispersal of asylum seekers in the city through pro-migrant activism. In Glasgow, work by local statutory organisations and community campaigns to address tensions and anti-migrant feeling and incidents was galvanised by the murder of an asylum seeker, Firsat Dag, in the city in 2001. Community-led campaigns to protect asylum seekers, such as the 'Glasgow Girls' campaigns, arose following this, particularly as people became integrated into local communities, importantly through attending school together. These networks have many characteristics of long-standing trade union and political organising that have strong traditions in the city. The campaigns have been important in galvanising politicians' and others' characterisations of Glasgow as being hospitable to newcomers.

Ideas of Glasgow (rather than just Scotland) as a particularly welcoming place in contrast to a hostile Home Office were also drawn on to counter the 'Go Home' campaign, in political speeches at demonstrations ('Glasgow is a welcoming city. It will take anyone to its heart that will love Glasgow back ... The only people we don't welcome is UKBA', Nina Baker, Green Party councillor, Emma's fieldnotes, 9 September 2013) and in an editorial in The Herald newspaper:

This attempt to intimidate asylum seekers in Glasgow seems to be of the same Home Office mindset. This is particularly offensive

\footnotetext{
${ }^{3}$ The 'Glasgow Girls' are a group of seven young women who first got together to campaign against the detention of one of their school friends, an asylum seeker whose claim had been refused. This grew into a campaign for the rights of all children asylum seekers. Their story was made into a musical which was then turned into a musical drama for the BBC (see Scottish Refugee Council, n.d.).
} 
because Glasgow has a proud history of welcoming refugees into the local community without the kind of friction that has been seen in some parts of the country.

(Herald View, 2013)

Such feelings were not only expressed by politicians and the media. There was a general feeling among the focus group with asylum seekers and refugees in Glasgow that Glasgow was a friendly place, that people there were accepting and that, although there was racism, it was better than other places. People talked about living in areas that were stigmatised and said that, although others thought these were bad places, for them this was home. Roselin, an asylum seeker from Zimbabwe, said:

People say Ibrox ${ }^{4}$ is a dangerous place to be, but to me I have never experienced that. I have been in that same place. For more than three years I have stayed in Glasgow, so it is like my birth home.

(Glasgow Focus Group, conducted by Emma)

In research in Glasgow for a previous project (AMICALL based at COMPAS, University of Oxford), Hannah was told by an officer in the local authority that the UK Border Agency had informed him that they found Glasgow to be the most difficult city in the UK from which to deport people whose asylum claims had been rejected. This was due to community-organised resistance campaigns which had physically prevented officers from entering properties to remove people, as well as mounting public demonstrations and letter-writing campaigns (Jones, 2012). This opposition between Glasgow activists and the Home Office is echoed in our current research by an activist who suggested that the decision to pilot the 'Go Home' posters in Glasgow might have been the Home Office testing whether pro-refugee activists were still able to mobilise:

Jean: I think from time to time they just, they're putting out feelers, 'have they finally got tired of it, has it finally calmed down up there?'

(Glasgow Activist Interview, conducted by Emma)

There are similarities in this excerpt with the Cardiff discussion of people being too 'barbaric' to accept a campaign like the vans. As

${ }^{4} \mathrm{~A}$ neighbourhood in Glasgow. 
such, Glasgow and Cardiff are presented as rebellious places, kicking against the government.

The particular histories of Glasgow and Cardiff as places of resistance - and as centres of dispersed asylum seekers - are important. Among the English case studies, we have found similar comparisons between cities with a good support infrastructure for refugees and those without. For example, in a Bradford focus group, Lucee explained:

I used to live in Leeds when I first came because I lived mainly in London and then I was brought to Leeds by the Immigration, and I found like in Leeds there was a few supporting groups, there weren't as many, they weren't like outreaching; when I came to Bradford I just found it's totally different, multicultural; I can get food from my country, you know like, there's all sorts going on, you know. And then there's all these support groups, you know, there was the BAFR, I mean Bradford Action for Refugees, Red Cross, BIASAN, together, I mean there are so many projects, so I found, yeah, in Bradford there is more support and obviously being in the City, centrally it's good.

(Bradford Focus Group, conducted by Hannah)

Like Glasgow and Cardiff, Bradford is a resettlement area for people seeking asylum. In the national imagination, Bradford tends to be discussed as a touchstone of community unrest associated with tensions between British Muslims and white British communities, centring on moments such as the burning of Salman Rushdie's The Satanic Verses and controversy about the racist headmaster Ray Honeyford in the 1980s (Burnett, 2009); riots in the 1980s and 2001 (Hussain and Bagguley, 2005; Pearce and Bujra, 2011) and recent mobilisations of the far-right and anti-Muslim English Defence League (EDL) (Treadwell, 2012). For activists we spoke to in the area, the major areas of unrest or worry tended to be around far-right mobilisations, with incidents in 2013 including UKIP electoral mobilisation and EDL provocations at mosques, rather than the Home Office migration rhetoric. However, the comments of refugees, asylum seekers and others also pointed to ways that immigration enforcement intervened in their daily lives, even if it was less visible in everyday public discourse of others. Similarly, Lucee's view, quoted above, of finding Bradford a relatively well-organised place in terms of refugee and asylum seeker support, contrasted with some activist views about local political organising. Pete, an activist Hannah interviewed in Bradford who had been involved in labour and migration politics in 
the area for decades, described the city as having plenty of people who would come to nostalgic film screenings about the miners' strike, but a more difficult place to mobilise demonstrations or direct action towards austerity or other current concerns.

Similarly, in the West Midlands an issue that emerged in interviews with activists was the difference between Birmingham and Coventry in terms of migrant and refugee organising. Coventry seemed to be a more conducive environment than Birmingham, which some saw as connected to Coventry's history as a city of peace and reconciliation. By contrast, organising in Birmingham seemed to be particularly difficult due to the fragmented layout of the city, as well as pressures for voluntary sector organisations (not limited to Birmingham) to adopt a 'servicing model' - whereby immigration professionals act on behalf of migrants and asylum seekers rather than migrants and asylum seekers advocating on their own behalf. Accounts emerged in one of the interviews about how Home Office imperatives to create a 'hostile environment' (see Chapter 2) were making it more difficult for voluntary sector organisations to support migrants and asylum seekers. ${ }^{5}$ In these English cities (Bradford, Coventry and Birmingham) the 'Go Home' messaging was experienced - and responded to - as less of a spectacular event and more as an adding of another layer to an already difficult situation for asylum seekers and refugees.

In contrast, perhaps the most immediate and spectacular moment of resistance we saw during the research was the Southall Black Sisters' spontaneous protest at Himalaya Palace, and its video recording (Malhi TV, 2013). As in Glasgow, this event provides an example of how long-standing anti-racist organisations can challenge divisive politics and mobilise networks of solidarity relatively quickly.

Some of the women who later contributed to the Ealing and Hounslow focus group discussions had been meeting at Southall Black Sisters (SBS), a women's centre in West London, and discussing media coverage of migration, cuts in access to welfare, proposals that welfare benefits claimants should undergo English language tests, government statements about restricting student entry into the country and proposals for the 2014 Immigration Bill (since passed

\footnotetext{
${ }^{5}$ Indeed, during our research two of the groups we were working with, Birmingham Asylum and Refugee Association (BARA) and Coventry Asylum and Refugee Action Group (CARAG), both lost their core funding after the Regional Asylum Association decided they would no longer fund self-organised asylum seekers' groups. However, BARA subsequently received $£ 8,000$ from the Lottery Fund.
} 
into law). The women viewed these developments as deeply worrying and inhumane and they discussed ways in which they could protest against these incursions. This was when an immigration enforcement van pulled up a few doors from the SBS centre's offices, and simmering unease ignited into spontaneous action.

A quick consensus was reached to go out on to the street to protest. The women scribbled slogans on to pieces of A3 paper, grabbed a megaphone, and started shouting 'UKBA go away'. They also decided it was important to warn local residents of the likelihood of a raid by sounding the alarm 'if you are illegal, run, leave the area, there's a raid going on!' (in Hindi). The women then followed the van to a small shopping centre. Enforcement officers had sealed the entrance to the shopping centre and they were questioning the small businesses and predominantly South Asian workers inside.

In a quick subversion of the Home Office agenda, they enacted their own 'hostile environment' by demonstrating at the entrance to the building and using a megaphone to amplify their opposition these officers were being made unwelcome and ashamed of what they were doing. They also made a point of shouting in Hindi so that local people could understand what was going on. Dozens of local shoppers and passers-by encircled the demonstrators, in solidarity or simply out of curiosity. Some of them voiced contrary opinions and some heated discussions ensued.

In this moment the street was seized, reclaimed and reorganised or 'reconstituted' as an offensive against anti-immigration controls. Furthermore, the YouTube video of this protest went viral. An image of one of the SBS workers became the logo for a network of activists the Anti Raids Network - issuing similar calls to join them in protest against immigration raids across London.

\section{Whose streets, whose place?}

Our research has shown how anti-immigration campaigns can make people more fearful about immigration. Here we have explored how place matters within these processes. We began by looking at the specific places where the Go Home van circulated. In these London boroughs the van was not experienced in a vacuum, but rather was experienced and interpreted within other neighbourhood struggles and histories and, in conjunction with other anti-immigration interventions. So in Barking and Dagenham this fed into feelings of 'us and them' (Anderson, 2013) - a division between migrants and nonmigrants. In Ealing and Hounslow, the van exacerbated frictions 
within the South Asian population, while protests against it gave voice to an alternative perspective (see also Chapter 5).

Perhaps unsurprisingly, the places where the vans circulated and/ or posters had been displayed are the places where we found most street-level opposition to the campaigns. Just as Twitter was used as a space for Home Office enforcement and was then reclaimed as a space for parody and organising (including the beginnings of this research project - see Living Research Five), in both Glasgow and Ealing and Hounslow protests sought to reclaim these localities through visible street protests. In Glasgow, this took the form of gathering behind the campaign banner 'Glasgow Campaign to Welcome Refugees' and cheering on speakers who promoted the idea of Glasgow as a welcoming place. In protests in Ealing and Hounslow, Southall Black Sisters proclaimed 'Whose streets? Our streets'. It should be emphasised that in both places these protests were not one-off events but came from networks with long-standing histories of protest and organising on immigration and refugee issues. Through these examples we can see how anti-immigration campaigns are not just rolled out over a flat terrain but reverberate through particular places differently.

We also saw how Operation Vaken fed into ideas of nation. Primarily and most notably we have explored here how an anti-anti-immigration position was taken by the Scottish National Party (SNP) in the run up to the Scottish Independence Referendum. In this context the posters took on added meaning as symbols of an unwelcoming and remote Westminster-based Home Office, highlighting the difference between a potential independent Scotland and the existing approach to immigration and asylum of the Westminster government. This did not unfold in the same way in Wales. Responses there had more in common with our Bradford and Birmingham case studies where the Operation Vaken campaign was seen as fanning the flames of racism and xenophobia but was not experienced as intensely as the places where the campaigns unfolded.

If we think of spaces as being continually produced, as suggested in the introduction to this chapter, we can also reflect on how immigration enforcement campaigns are a part of the production of space. They contribute to how space is practised (Lefebvre, 1991) - the experience of seeing an anti-immigration van on your local high street and deciding to take a different route tomorrow. They feed into how officials conceive of and represent spaces; think of the van circulating in Barking and Dagenham, stirring up ill feeling and adding to the perception of those watching from afar of a divided community. But crucially they also produce new spaces and platforms for forms of 
protest and the creation of other ideas of what specific locations could mean, resonating in the chant: 'Whose streets? Our streets!'

\section{References}

Anderson, B. (2013) Us and Them?: The Dangerous Politics of Immigration Control, Oxford, Oxford University Press.

Asthana, A. (2010) 'Target BNP: A battle for the soul of east London', The Guardian, 21 March, www.theguardian.com/politics/2010/ mar/21/bnp-dagenham-barking-elections [last accessed 22 May 2016].

Bammer, A. (1992) 'Editorial: The question of "home" ', New Formations, 17: vii-xi.

Burnett, J. (2009) 'Racism and the state: authoritarianism and coercion', in R. Coleman, J. Sim, S. Tombs and D. Whyte (eds), State, Power, Crime, Los Angeles: Sage, pp. 49-61.

Cantle, T. (2001) Community Cohesion: A Report of the Independent Review Team, London: Home Office.

Foucault, M. (1986) 'Of other spaces', Diacritics, 16 (1): 22-7.

Harries, B. (2015) " "Yma o hyd? Gwyn o hyd? (Still here? Still white?)" Racism, identity and nationalism in post-devolution Wales', Paper presented at Racism and Nationalism after the Scottish Referendum and 2015 General Election, Birkbeck, London, 11 November.

Herald View (2013) 'Campaign that is not wanted here', Herald Scotland, 30 August, www.heraldscotland.com/opinion/13120517.Campaign_ that_is_not_wanted_here/ [last accessed 22 May 2016].

Hudson, P. (2009) ' 80 years of Ford at Dagenham', The Telegraph, 15 May, www.telegraph.co.uk/motoring/classiccars/5318900/80-yearsof-Ford-at-Dagenham.html [last accessed 22 May 2016].

Hussain, Y. and Bagguley, P. (2005) 'Citizenship, ethnicity and identity: British Pakistanis after the 2001 "riots" ', Sociology, 39 (3): 407-25.

Jones, H. (2012) Attitudes to Migrants, Communication and Local Leadership: Country Research Report - UK, Oxford: COMPAS.

Jones, H. (2013) Negotiating Cohesion, Inequality and Change: Uncomfortable Positions in Local Government, Bristol: Policy Press.

Lefebvre, H. (1991) The Production of Space, Oxford: Blackwell.

London Borough of Barking and Dagenham (n.d.) 'Summary of the 2011 Census results for Barking and Dagenham', www.lbbd.gov.uk/ council/statistics-and-data/census-information/2011-census/ [last accessed 22 May 2016].

Malhi TV (2013) Southall Black Sisters Against Enforcement Team in Southall, YouTube, www.youtube.com/watch?v=pQ0_TFBVots [last accessed 22 May 2016].

Massey, D. (1994) Space, Place, Gender, Cambridge: Polity. 
Payson, A. (2015) 'Moving feelings, intimate moods and migrant protest in Cardiff', fOMEC fournal: fournalism, Media and Cultural Studies, 7: 1-16, http://www.cardiff.ac.uk/jomec/research/ journalsandpublications/jomecjournal/7\%20-\%20june2015/ index.html [last accessed 2 February 2016].

Pearce, J. and Bujra, J. (2011) Saturday Night and Sunday Morning: The Story of the Bradford Riots, Bradford: Vertical Editions.

Probyn, E. (1996) Outside Belongings, London and New York: Routledge.

Sassen, S. (1991) The Global City: Nerw York, London, Tokyo, Princeton, Princeton University Press.

Scottish Government (2013) Scotland's Future:Your Guide to an Independent Scotland, Edinburgh: The Scottish Government, www.gov.scot/ Resource/0043/00439021.pdf [last accessed 22 May 2016].

Scottish Refugee Council (n.d.) 'The Glasgow Girls', www. scottishrefugeecouncil.org.uk/news_and_events/get_involved_in_ arts_events/glasgow_girls [last accessed 22 May 2016].

Simmons, D. (2014) A Study of the Transition to Parenthood in Barking and Dagenham, Examining the Experiences of UK Born and Migrating Parents, PhD thesis, University of Greenwich.

Treadwell, J. (2012) 'White Riot: The English Defence League and the 2011 English riots', Criminal fustice Matters, 87(1): 36-7.

Vertovec, S. (2007) 'Super-diversity and its implications', Ethnic and Racial Studies, 30 (6):1024-54. 